\title{
FeO content estimation in steel slag using Raman spectroscopy in NIR range
}

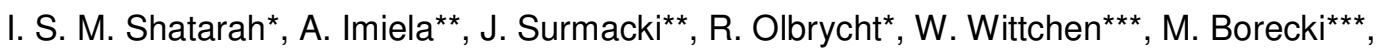 \\ H. Abramczyk**, B. Więcek*
}

\begin{abstract}
*Lodz University of Technology, Institute of Electronics, 211/215 Wólczańska St.90-924 Łódź, Poland, iyad.shatarah@gmail.com

${ }^{* \star}$ Lodz University of Technology, Institute of Applied Radiation Chemistry, Wróblewskiego 15 St. 93-590 Lodz, Poland, abramczy@mitr.p.lodz.pl

${ }^{* * \star}$ Institute for Ferrous Metallurgy, K.Miarki12-14 St.,44-100 Gliwice, Poland, wwittchen@imz.pl
\end{abstract}

\begin{abstract}
The knowledge about $\mathrm{FeO}$ content in steel slags after the discharge process is very important for steelmaking and it influences the latter technological process. Currently used methods require inserting a probe into the ladle. Then the slag is sent and analyzed in the laboratory. As it is a time consuming process, the authors propose a novel method of $\mathrm{FeO}$ content estimation, based on the use of Raman spectroscopy. Its main advantage is instantaneous result of the steel slag composition measurement.
\end{abstract}

\section{Introduction}

Steel slag consists of metal oxides and silicon dioxides. FeO content in steel slag determines the quality of the steel as it provides information about its oxidation degree. Currently, a few different techniques are used for analyzing the FeO content in steel slag. Among them the mostly used are mathematical modeling [1], X-ray fluorescence spectrometry [2] and thermography [3].The Raman spectroscopy is used in many applications, such as medicine [4], chemistry [5] and remote sensing [6]. This technique can be applied for quantitative analyzes and identification of chemical content basing on scattered radiation caused by the molecular vibrations. In theory all know the Rayleigh elastic and Raman and Brillion scattering [7]. This study presents the use of Raman spectroscopy for estimation of FeO content in steel slag using the laser light in NIR spectral range.

\section{Importance of slag in metallurgical process}

Metallurgical slag is a multi-component compound, mainly of oxides, which in playsa crucial role in metallurgical processes. In liquid state, slag is regarded as an ionic liquid [8], however in practice, usually slags are approached in line with molecular theory as multi-component solutions, which is sufficient for utilitarian description of metallurgical processes $[9,10,16]$. Substantially, metallurgical slag is a by-product of crude iron and steel manufacturing. In the steelmaking process it absorbs chemical compounds formed as a result of refining (additives oxidation), desulphurization, dephosphorization and deoxidation of steel as well as wear of refractory lining, and a result of absorption of impurities introduced along with charge material $[8,9]$.

Steelmaking slag, is of much lower density than iron, reaching from $3200-3600 \mathrm{~kg} / \mathrm{m}^{3}$, depending on the composition, floats on the surface of steel, thus forming a layer with chemical impact on metal and isolating the metal from atmospheric air. The slag, absorbing products of metallurgical reactions, alters its chemical composition during the process.

Presence of particular components in slag and mutual proportions between them decide on slag's interaction with steel, and as a corollary on the properties of steel. The most significant oxides composing steelmaking slag are $\mathrm{CaO}, \mathrm{SiO}_{2}, \mathrm{MgO}, \mathrm{Al}_{2} \mathrm{O}_{3}, \mathrm{FeO}, \mathrm{MnO}, \mathrm{P}_{2} \mathrm{O}_{5}, \mathrm{Fe}_{2} \mathrm{O}_{3}$, and among others $\mathrm{Cr}_{2} \mathrm{O}_{3}, \mathrm{TiO}_{2}, \mathrm{Na}_{2} \mathrm{O}, \mathrm{K}_{2} \mathrm{O}$ and other are also important. $\mathrm{CaF}_{2}, \mathrm{CaS}, \mathrm{CaC}_{2}$ are to be deemed the most important non-oxide compounds $[11,12,15,16]$. FeO concentration in slag in steelmaking processes is of very significant meaning, and thus knowledge of the said parameter facilitates application of adequate technological procedures and improves production process. Value of the said parameter is intentionally altered during steel melting as at various stages of production; various goals are pursued, which requires various interaction of slag and steel. For example, presence of $\mathrm{FeO}$ in slag facilitates dephosphorization of steel $[9,11]$. Due to that, steel is usually subject to dephosphorization during refining in steelmaking furnace, as at that time slag is rich in iron oxide (dozen or more per cent).

Completely different requirements concerning slag are valid during ladle treatment. At this stage of production, one aims at elimination of FeO from slag $[10,17]$. The desired low content of these oxides in slag stems from the conditions required in steel deoxidation and desulphurization $[13,16,18]$, which occur during ladle treatment. 
Knowledge of FeO concentration in steelmaking slag allows to optimize slag deoxidation, and as a corollary the use of deoxidants, thus impacts production cost and metallurgical purity of steel. However estimation of FeO concentration in slag, based on balance calculations is difficult, as the said oxide is a product of oxidation of main component of charge material, i.e. iron [14].

Samples of the slag described in this paper (fig. 3-8) were collected from the Electrical Arc Furnace (EAF) in the different phases of the production process. Samples were examined in the chemical laboratory in order to mark chemical composition according to the procedures shown in the table 1.

Table 1.Procedures for testing slag composition

\begin{tabular}{|l|l|}
\hline Indication & Testing procedure, method used, equipment \\
\hline $\mathrm{Al}_{2} \mathrm{O}_{3}$ & \\
$\mathrm{CaO}$ & \\
$\mathrm{Fe}$ & ICP-OES Instruments 5100 ICP-OES [19] \\
$\mathrm{MgO}$ & \\
$\mathrm{MnO}$ & \\
$\mathrm{P}_{2} \mathrm{O}_{5}$ & \\
$\mathrm{SiO}_{2}$ & Titrimetric analysis \\
\hline $\mathrm{Fe}(\mathrm{II}+\mathrm{III})$ & \\
$\mathrm{Fe}$ met & Coulometric method, Coulomat 702 SO/CS [20] \\
\hline $\mathrm{S}$ &
\end{tabular}

\section{Raman spectroscopy}

Raman spectroscopy is an advanced radiation method used already in different applications [4, 5, 6]. The main idea of Raman scattering, which differentiates it from Rayleigh one, relies on the shift of frequency of a monochromatic light, resulting from the coupling between the molecules vibrational energy levels and the incident radiation as shown in figure 1 [21]. For Raman Stokes scattered radiation, the final energy state E2 is higher than the initial state E1, the molecule is exited from. For Raman anti-Stokes radiation, the initial energy state is E2. The interaction between the molecule and an incident photon moves it to a virtual energy state $\mathrm{E}_{4}$, and then the molecule's energy drops to lower, final state $E_{1}[7]$.

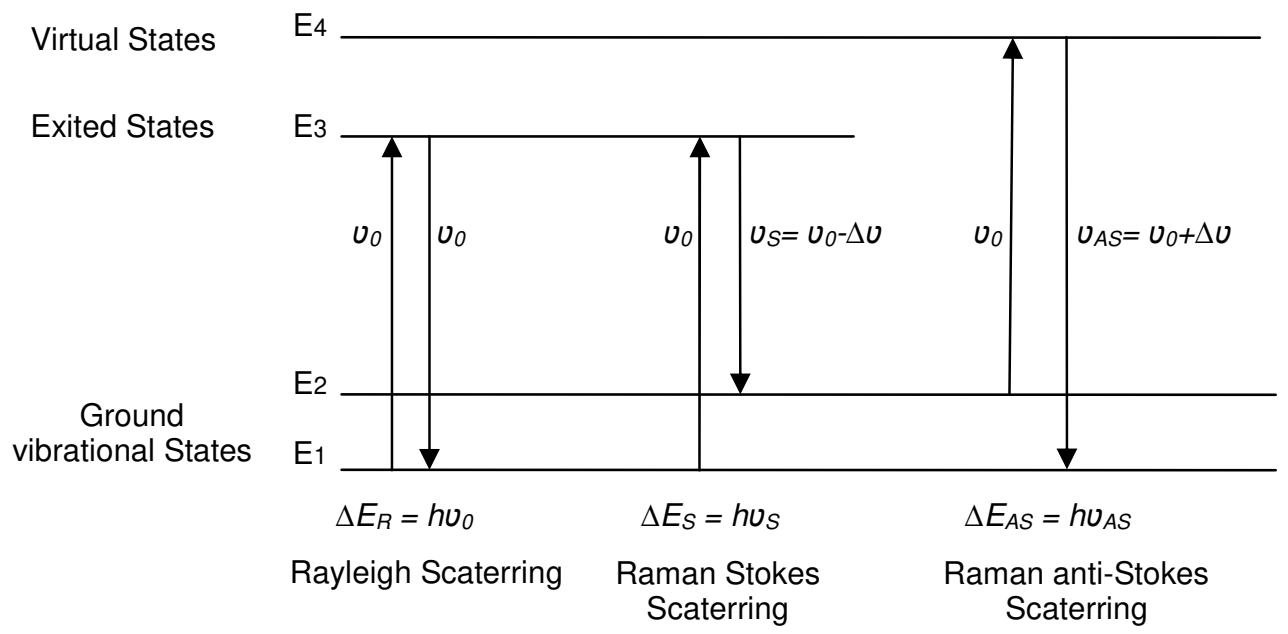

Fig. 1: Spectroscopic transitions underlying several types of vibrational spectroscopy. $v_{0}$ is the source laser wavenumber, while $\Delta u$ is the Raman shift[21]

In chemistry, the backscattered Raman spectra contain information about the structure and chemical composition of a sample. It is indicated by the Raman shift. In addition, this technique provides essential information about the concentration of the compositions. The concentration is indicated by the Raman scattered radiation intensity. One must notice that the Raman spectroscopy signals are very weak. In consequence, it requires better optics in comparison to absorption methods such as e.g. Fourier transform infrared spectroscopy. Another essential matter that plays an important role is the compatibility and alignment of Raman spectroscopy system for a given application, in order to obtain accurate and reproducible results for quantitative measurements. Laser power, frequency stability, polarization 
of light and path length has to be taken into consideration[21]. It is important to know that anti-Stokes scattered radiation strongly depends on temperature. This effect is successfully used in Distributed Temperature Sensing (DTS) $[6,7]$.

\section{Materials and experimental setup}

In this research, one examined 6 samples of steel slag, with different chemical compositions and in solid and powder forms. Figure 2 presents an exemplary piece of the solid steel slag and its microscopic view.

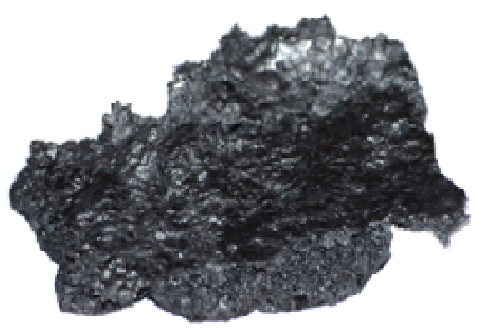

(a)

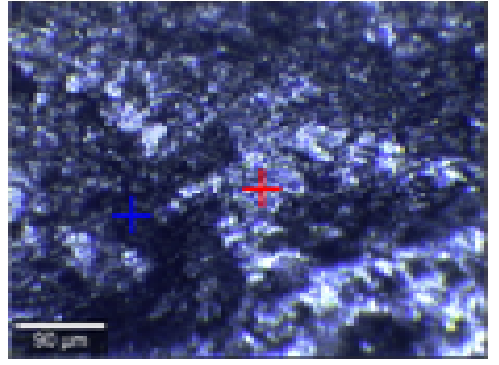

(b)

Fig. 2: Exemplary piece of the tested steel slag (a), microscopic view of the steel slag piece (b)

HT Raman Spectrometer by EmVision was used in the tests. It operates with NIR laser source at the wavelength $\lambda=785 \mathrm{~nm}$, with maximum power $\mathrm{P}=20 \mathrm{~mW}$ [27]. This device is combined with a high performance Raman filters integrated in the fibre optic probe. The laser light is delivered into investigated sample through the light guide. The backscattered waves are then directed to the Raman spectrometer by a directional coupler. Figure 3 presents the block diagram of the testing system. The Raman spectrometer is delivered with special software, which helps reading the backscattered signals' wavenumbers. Analysing the backscattered signals allows obtaining information about the content of $\mathrm{FeO}$ and other metal oxides in steel slag samples.

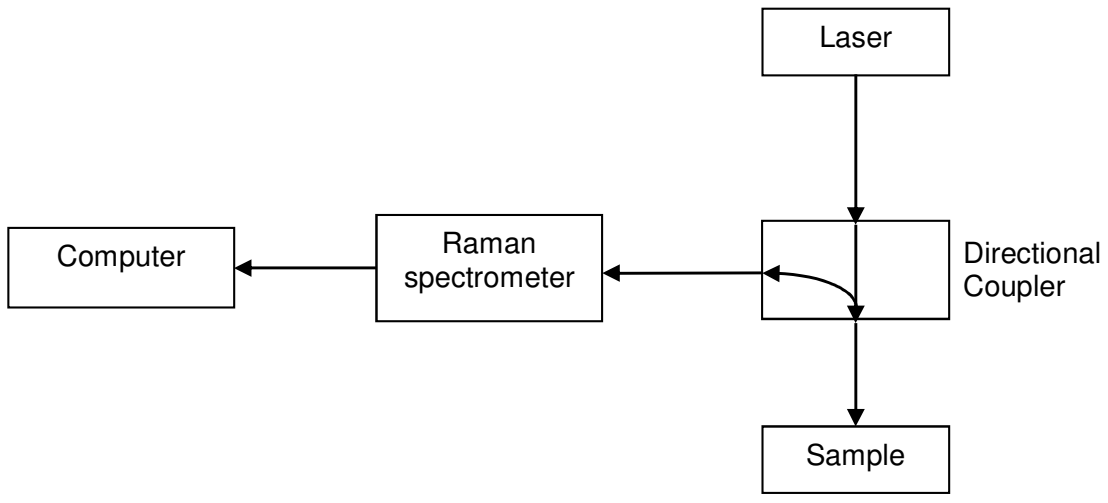

Fig. 3: Block diagram of the testing system

\section{Exemplary results}

Figures 4-9 present the chemical composition and the obtained Raman spectra corresponding to the investigated samples. Based on the data in literature, one can find the Raman shifts for the chemical compounds for the wavelength of used NIR laser source $\lambda=785 \mathrm{~nm}$.

For example, for iron oxides $\mathrm{FeO}, \mathrm{Fe}_{2} \mathrm{O}_{3}$ and $\mathrm{Fe}_{3} \mathrm{O}_{4}$, Raman scattered radiation can be observed in the spectral range $600-750 \mathrm{~cm}^{-1}$ [22] [23]. For aluminium oxide (alumina) $\mathrm{Al}_{2} \mathrm{O}_{3}$, the return scattered radiation is at $420 \mathrm{~cm}^{-1}$ [24], for $\mathrm{CaO}$ at $1080 \mathrm{~cm}^{-1}$ [25] and for $\mathrm{MgO}$ the peak of radiation appears at $617 \mathrm{~cm}^{-1}$ [26]. Due to the high concentration of iron oxides in the slag samples, the highest intensity is obtained at $612 \mathrm{~cm}^{-1}$. The results of our tests confirm the spectral ranges of Raman scattered radiation found in the scientific literature. Some insignificant shifts to higher or lower values of wavelength were also observed. These shifts might have shown up due to the diversity of the chemical composition of the tested samples. It is remarkable, that the wavenumbers, at which the peaks emerge, are the same for all samples. It denotes that the Raman spectroscopy is a reproducible and precise method. In addition, the Raman spectra intensities vary due to the difference of concentration of metal oxides in each of the measured samples. 


\begin{tabular}{l|l|l} 
Sample & \multicolumn{2}{|l}{$1 \mathrm{~A} 105693$} \\
\hline Indication & $\begin{array}{l}\text { Measurments } \\
\text { unit }\end{array}$ & Result \\
\hline $\mathrm{Al}_{2} \mathrm{O}_{3}$ & $\%$ & 4.09 \\
\hline $\mathrm{CaO}$ & $\%$ & 22.46 \\
\hline $\mathrm{Fe}$ & $\%$ & 37.24 \\
\hline $\mathrm{Fe}(\mathrm{II}+\mathrm{III})$ & $\%$ & 31.1 \\
\hline $\mathrm{Femet}$ & $\%$ & 6.14 \\
\hline $\mathrm{MgO}$ & $\%$ & 4.06 \\
\hline $\mathrm{MnO}$ & $\%$ & 8.20 \\
\hline $\mathrm{P}_{2} \mathrm{O}_{5}$ & $\%$ & 0.28 \\
\hline $\mathrm{S}$ & $\%$ & $<0.01$ \\
\hline $\mathrm{SiO}_{2}$ & $\%$ & 13.79
\end{tabular}

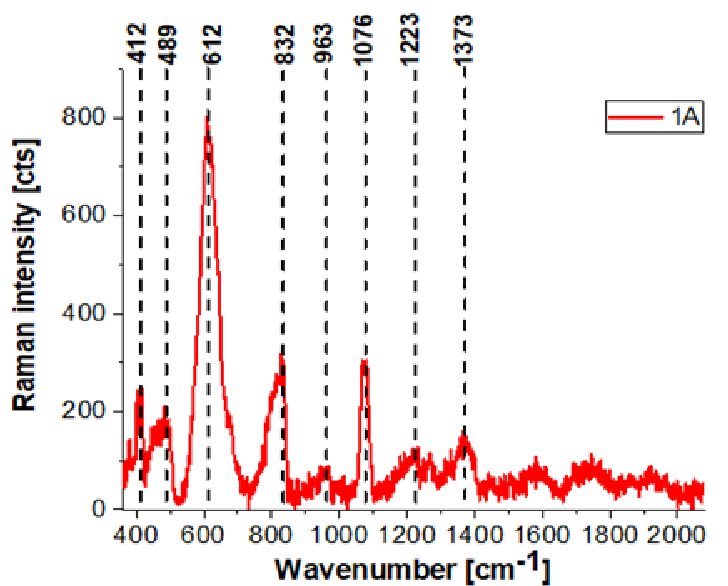

Fig. 4: Chemical composition of the sample $1 A$ and its Raman spectrum acquired using NIR laser with power $P=20 \mathrm{~mW}$ and wavelength $\lambda=785 \mathrm{~nm}$

\begin{tabular}{l|l|l} 
Sample & \multicolumn{2}{|l}{$1 \mathrm{~B} 105693$} \\
\hline Indication & $\begin{array}{l}\text { Measurment } \\
\text { unit }\end{array}$ & Result \\
\hline $\mathrm{Al}_{2} \mathrm{O}_{3}$ & $\%$ & 5.69 \\
\hline $\mathrm{CaO}$ & $\%$ & 31.87 \\
\hline $\mathrm{Fe}$ & $\%$ & 31.13 \\
\hline $\mathrm{Fe}(\mathrm{II}+\mathrm{III})$ & $\%$ & 29.22 \\
\hline Femet & $\%$ & 1.90 \\
\hline $\mathrm{MgO}$ & $\%$ & 3.71 \\
\hline $\mathrm{MnO}$ & $\%$ & 7.06 \\
\hline $\mathrm{P}_{2} \mathrm{O}_{5}$ & $\%$ & 0.21 \\
\hline $\mathrm{S}$ & $\%$ & $<0.01$ \\
\hline $\mathrm{SiO}_{2}$ & $\%$ & 12.95 \\
\hline
\end{tabular}

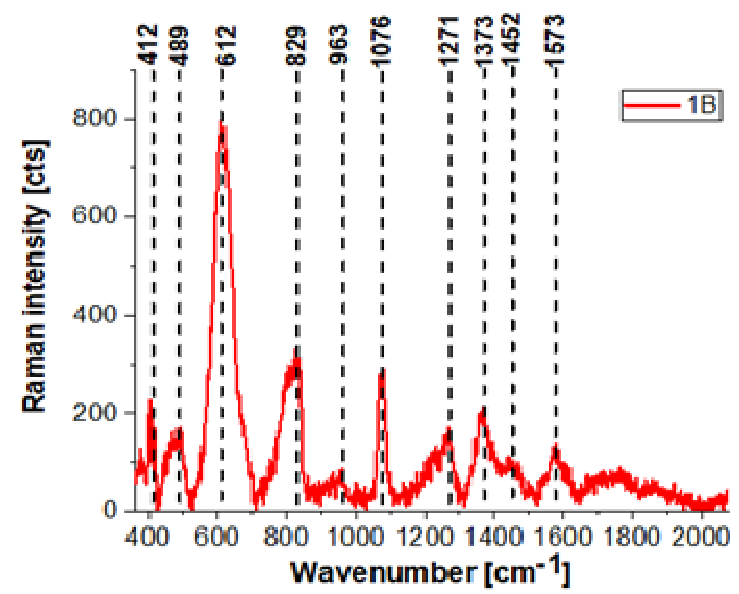

Fig. 5: Chemical composition of the sample $1 B$ and its Raman spectrum acquired using NIR laser with power $P=20 \mathrm{~mW}$ and wavelength $\lambda=785 \mathrm{~nm}$

\begin{tabular}{l|l|l} 
Sample & \multicolumn{2}{|l}{$1 \mathrm{C} \mathbf{1 0 5 6 3}$} \\
\hline Indication & $\begin{array}{l}\text { Measurment } \\
\text { unit }\end{array}$ & Result \\
\hline $\mathrm{Al}_{2} \mathrm{O}_{3}$ & $\%$ & 4.07 \\
\hline $\mathrm{CaO}$ & $\%$ & 25.95 \\
\hline $\mathrm{Fe}$ & $\%$ & 38.30 \\
\hline $\mathrm{Fe}(\mathrm{II}+\mathrm{III})$ & $\%$ & 34.17 \\
\hline Femet & $\%$ & 4.13 \\
\hline $\mathrm{MgO}$ & $\%$ & 4.06 \\
\hline $\mathrm{MnO}$ & $\%$ & 6.51 \\
\hline $\mathrm{P}_{2} \mathrm{O}_{5}$ & $\%$ & 0.12 \\
\hline $\mathrm{S}$ & $\%$ & 0.03 \\
\hline $\mathrm{SiO}$ & $\%$ & 12.58
\end{tabular}

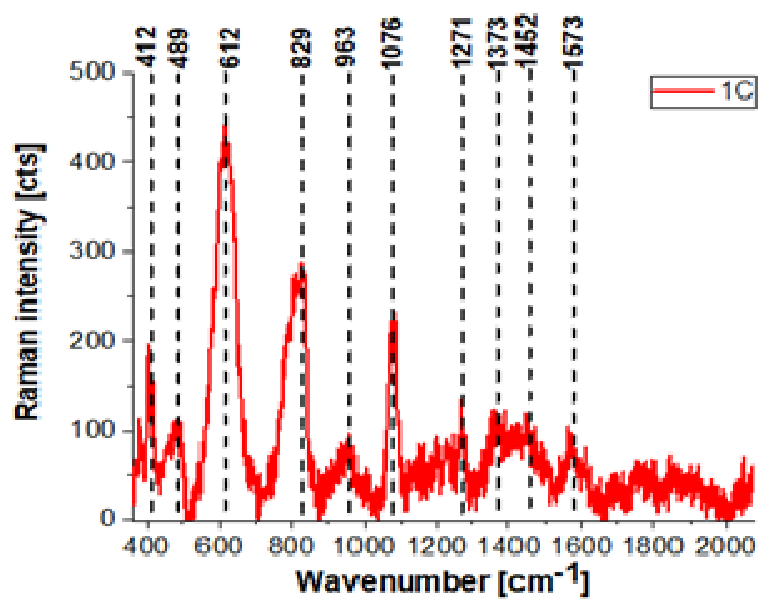

Fig. 6: Chemical composition of the sample $1 C$ and its Raman spectrum acquired using NIR laser with power $P=20 \mathrm{~mW}$ and wavelength $\lambda=785 \mathrm{~nm}$ 


\begin{tabular}{l|l|l} 
Sample & \multicolumn{2}{|l}{$2 \mathrm{~A} \mathbf{1 0 5 7 5 4}$} \\
\hline Indication & $\begin{array}{l}\text { Measurment } \\
\text { unit }\end{array}$ & Result \\
\hline $\mathrm{Al}_{2} \mathrm{O}_{3}$ & $\%$ & 7.07 \\
\hline $\mathrm{CaO}$ & $\%$ & 24.16 \\
\hline $\mathrm{Fe}$ & $\%$ & 30.97 \\
\hline $\mathrm{Fe}$ (II + III) & $\%$ & 27.84 \\
\hline $\mathrm{Femet}$ & $\%$ & 3.13 \\
\hline $\mathrm{MgO}$ & $\%$ & 5.39 \\
\hline $\mathrm{MnO}$ & $\%$ & 7.11 \\
\hline $\mathrm{P}_{2} \mathrm{O}_{5}$ & $\%$ & 0.20 \\
\hline $\mathrm{S}$ & $\%$ & $<0.01$ \\
\hline $\mathrm{SiO}_{3}$ & $\%$ & 16.85 \\
\hline
\end{tabular}

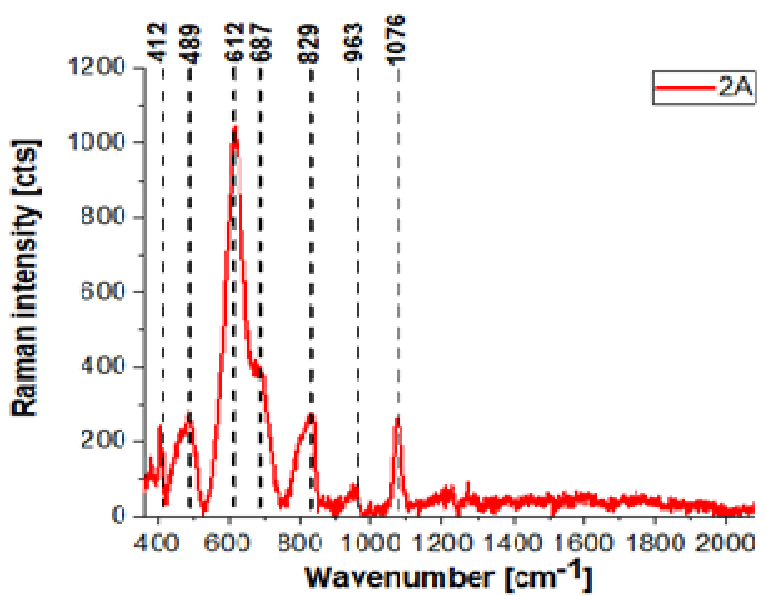

Fig. 7: Chemical composition of the sample $2 A$ and its Raman spectrum acquired using NIR laser with power $P=20 \mathrm{~mW}$ and wavelength $\lambda=785 \mathrm{~nm}$

\begin{tabular}{l|l|l} 
Sample & \multicolumn{2}{|l}{$2 \mathrm{~B} \mathrm{105754}$} \\
\hline Indication & $\begin{array}{l}\text { Measurment } \\
\text { unit }\end{array}$ & Result \\
\hline $\mathrm{Al}_{2} \mathrm{O}_{3}$ & $\%$ & 8.04 \\
\hline $\mathrm{CaO}$ & $\%$ & 27.57 \\
\hline $\mathrm{Fe}$ & $\%$ & 24.67 \\
\hline $\mathrm{Fe}(\mathrm{II}+\mathrm{III})$ & $\%$ & 22.44 \\
\hline Femet & $\%$ & 2.23 \\
\hline $\mathrm{MgO}$ & $\%$ & 5.34 \\
\hline $\mathrm{MnO}$ & $\%$ & 7.24 \\
\hline $\mathrm{P}_{2} \mathrm{O}_{5}$ & $\%$ & 0.23 \\
\hline $\mathrm{S}$ & $\%$ & 0.02 \\
\hline $\mathrm{SiO}_{2}$ & $\%$ & 19.11
\end{tabular}

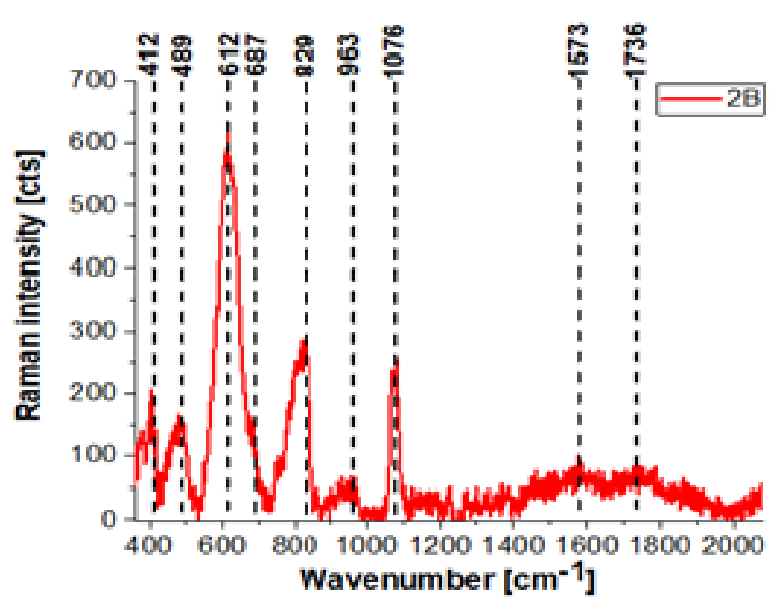

Fig. 8: Chemical composition of the sample $2 B$ and its Raman spectrum acquired using NIR laser with power $P=20 \mathrm{~mW}$ and wavelength $\lambda=785 \mathrm{~nm}$

\begin{tabular}{l|l|l} 
Sample & \multicolumn{2}{|l}{$\mathbf{2 C} \mathbf{1 0 5 7 5 4}$} \\
\hline Indication & $\begin{array}{l}\text { Measurment } \\
\text { unit }\end{array}$ & Result \\
\hline $\mathrm{Al}_{2} \mathrm{O}_{3}$ & $\%$ & 7.85 \\
\hline $\mathrm{CaO}$ & $\%$ & 26.04 \\
\hline $\mathrm{Fe}$ & $\%$ & 28.82 \\
\hline $\mathrm{Fe}(\mathrm{II}+\mathrm{III})$ & $\%$ & 24.35 \\
\hline $\mathrm{Femet}$ & $\%$ & 4.47 \\
\hline $\mathrm{MgO}$ & $\%$ & $\mathbf{5 . 4 0}$ \\
\hline $\mathrm{MnO}$ & $\%$ & 7.06 \\
\hline $\mathrm{P}_{2} \mathrm{O}_{5}$ & $\%$ & 0.19 \\
\hline $\mathrm{S}$ & $\%$ & 0.02 \\
\hline $\mathrm{SiO}_{2}$ & $\%$ & 17.11 \\
\hline & &
\end{tabular}

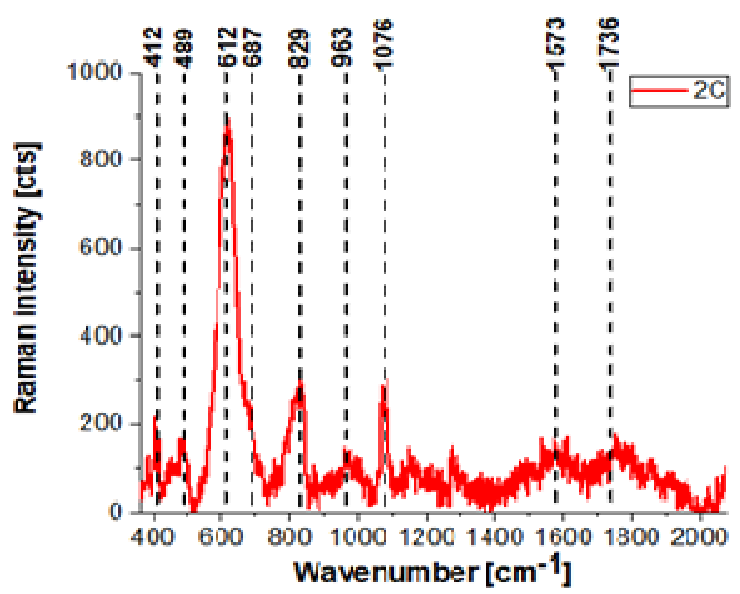

Fig. 9: Chemical composition of the sample $2 C$ and its Raman spectrum acquired using NIR laser with power $P=20 \mathrm{~mW}$ and wavelength $\lambda=785 \mathrm{~nm}$ 


\section{Conclusion}

Steel slag content is studied using several methods, in order to obtain information about the steel quality and the effectiveness of steelmaking process. Raman spectroscopy provides detailed information about the material content of the slag. The intensity of Raman scattered radiation refers to the concentration of a particular compound in the slag. For some materials the spectral ranges of Raman radiation are overlapping. Previous Raman spectroscopy studies focused on the examination of individual metals separately. The method presented in this paper implements Raman spectroscopy to study steel slag containing several metals and oxides. In addition, this method is useful for estimation the oxides content in steel slag, as shown by the Raman shift values. Subsequent studies are planned, with better calibration and accuracy, in order to obtain quantitative results for different oxides in steel slags.

\section{REFERENCES}

[1] StrandhJ.,Nakajima K., Eriksson R., Johnsson P.,A Mathematical Model to Study Liquid Inclusion Behaviour at the Steel-Slag Interface. ISIJ International, vol. 45, no. 12, 2005,pp. 1838-1847.

[2] Tong X. M., Zhao H. F., Huang C. Y., Zhao Y. B., Determination of 13 components in slag by X-ray fluorescence spectrometry.

[3] Pacholski K., Więcek B., Wittchen W., Borecki M., IR radiation parameters for estimating metallurgical properties of steel slag. PAK, vol. 57, nr. 10, 2011, pp.1245-1248.

[4] Abramczyk H., Kopeć M., Application of Raman scattering in biomedicine, telecommunication and thermometry. Measurment Automation Monitoring, vol. 63, nr. 2, 2017, pp. 38-40.

[5] Seitz W. R., Chemical Sensors Based on Fiber Optics. Analytical Chemistry, vol. 56, no. 1,1948,pp.16-22.

[6] Farahani M. A., Gogolla T., Spontaneous Raman Scattering in Optical Fibers with Modulated Probe Light for Distributed Temperature Raman Remote Sensing. Journal of Lightwave Technology, vol. 17, no. 8, 1999, pp. 13791391.

[7] Shatarah I. S. M., Olbrycht R.,Distributed temperature sensing in optical fibers based on Raman scattering: theory and applications. Measurement Automation Monitoring, vol. 63, no. 02, 2017, pp. 41-44.

[8] Botor J., Podstawymetalurgicznejinżynieriiprocesowej/Foundations of metallurgical process engineering/, Issued by: WydawnictwoPolitechnikiŚląskiej, Gliwice, 1999.

[9] Głownia J., Kalandyk B., Zapała R., Sobula S., Tęcza G., Malatyńska P., Telejko I., Brzeziński M., Charakterystyka stali na odlewy/Characteristics ofsteel for castings/, Issued by: Wydawnictwa AGH, Kraków, 2010.

[10] Ghosh A., Secondary Steelmaking, CRC Press, Boca Raton, Florida, USA, 2000.

[11] Turgdogan E.T., Fundamentals of Steelmaking, The Institute of Materials, London, UK, 1996,

[12] Piech J., Wyłożeniaogniotrwałepieców i urządzeńcieplnych/Refractory lining of furnaces and heating equipment/, Issued by: Wydawnictwa AGH, Kraków, 1999.

[13] HoltzerM., Procesymetalurgiczne i odlewniczestopówżelazapodstawyfizykochemiczne, /Metallurgical and casting processes of iron alloys; physico-chemical foundations/ Issued by: PWN, Warszawa 2013.

[14] Fine H. A., Geiger G. H., Handbook on Material and Energy Balance Calculations in Metallurgical Processes, The Metallurgical Society of AIME Warrendale, Pennsylvania, USA, 1983.

[15] StrąkowskiR., PacholskiK., WięcekB., OlbrychtR., WittchenW., BoreckiM., Estimation of FeO content in the steel slag using infrared imaging and artificial neural network, Measurement, vol. 117 (2018),pp. 380-389.

[16] Han Ch., Chen M., Zhang W., Zhao Z., Evans T., Evaluation of Existing Viscosity Data and Models and Developments of New Viscosity Model for Fully Liquid Slag in the SiO2-Al2O3-CaO-MgO System, Metallurgical and Materials Transactions B, vol. 47B, October, 2016, pp. 2861- 2874.

[17] Zhao D., Li G., Wang H., Ma J., Slag/Metal Separation from H2-Reduced High Phosphorus Oolitic Hematite, ISIJ International, vol. 57 (2017), no. 12, pp. 2131-2140.

[18] Ma X., Chen M.,Xu H., Zhu J., Wang G., Zhao B., Sulphide Capacity of CaO-SiO2-Al2O3-MgO System Relevant to Low MgO Blast Furnace Slags, ISIJ, International, vol. 56 (2016), no. 12, pp. 2126-2131.

[19] https://www.agilent.com/en/products/icp-oes/icp-oes-instruments/5100-icp-oes

[20] https://www.mtm.kuleuven.be/equipment/Coulomat/Coulomat

[21] McCreery R. L., Raman Spectroscopy for Chemical Analysis, John Wiley \& Sons, Inc., New York, 2000.

[22] Strobel R., Pratsinis R. E., Direct synthesis of maghemite, magnetite and wustite nanoparticles by flame spray pyrolysis. Advanced Powder Technology, vol. 20 (2009), pp. 190-194.

[23] Lu J-F., Tsai C-J., Hydrothermal phase transformation of hematite to magnetite. Nanoscale Research Letters, 2014, 9:230.

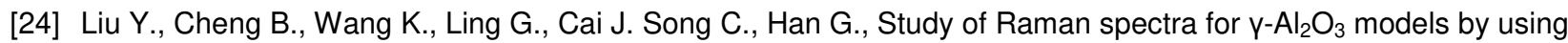
first-principles method. Solid State Communications, vol. 178 (2014), pp. 16-22.

[25] Schmid T., Dariz P., Shedding light onto the spectra of lime: Raman and luminescence bands of $\mathrm{CaO}, \mathrm{Ca}(\mathrm{OH}) 2$ and $\mathrm{CaCO}_{3}$. Journal of Raman Spectroscopy, vol. 46 (2015), pp. 141-146.

[26] Khambata S. J., Raman Spectrum of Magnesium Oxide. Proc. Phys. Soc. London, Sect. A 69, 426 (1956).

[27] http://www.emvisionllc.com/index-Products.html 